\title{
PENGARUH LINGKUNGAN KERJA DAN STRES KERJA TERHADAP KINERJA PERAWAT PADA RSU KERTHA USADA DI TENGAH PANDEMI COVID - 19
}

\author{
L. P. Rismayanti ${ }^{1}$, N.M.D.A. Mayasari ${ }^{2}$ \\ ${ }^{1}$ Jurusan Manajemen, Universitas Pendidikan Ganesha, Singaraja \\ e-mail : pasekrismayanti@gmail.com, dwi.mayasari@undiksha.ac.id
}

\begin{abstract}
Abstrak
Penelitian ini bertujuan untuk mengetahui pengaruh lingkungan kerja dan stres kerja terhadap kinerja perawat pada RSU Kertha Usada ditengah pandemi COVID-19. Dengan mengkaji tiga variabel yaitu variabel bebas lingkungan kerja dan stres kerja dan kinerja sebagai variabel terikat. Penelitian ini melibatkan 107 sampel perawat tetap di RSU Kertha Usada. Data dikumpulkan dengan metode kuisioner dan dianalisis dengan analisis jalur. Hasil penelitian menunjukkan bahwa (1) Lingkungan kerja dan stres kerja berpengaruh signifikan terhadap kinerja sebesar 24,1\%. (2) Lingkungan kerja berpengaruh positif dan signifikan terhadap kinerja sebesar 36,3\%. (3) Stres kerja secara negatif dan signifikan berpengaruh terhadap kinerja sebesar 22,9\%. (4) Secara negatif dan signifikan lingkungan kerja berpengaruh terhadap stres kerja sebesar $34,0 \%$.
\end{abstract}

Kata Kunci : kinerja, lingkungan kerja, stres kerja

\begin{abstract}
This study aims to determine effect of work environment and work stress on the performance of nurses at RSU Kertha Usada amid the COVID-19 pandemic. By examining three variables, namely work environment and work stress as independent variables and performance as dependent variables. This study involved 107 samples of permanent nurses at RSU Kertha Usada. Data were collected using a questionnaire method and analyzed using path analysis. The results showed that (1) work environment and work stress have a significant effect on performance by $24.1 \%$. (2) The work environment has a positive and significant effect on performance by $36.3 \%$. (3) Job stress has a negative and significant effect on performance by $22.9 \%$. (4) The work environment negatively and significantly affects work stress by $34.0 \%$.
\end{abstract}

Keywords: performance, work environment, work stress

\section{Pendahuluan}

Manusia sebagai makhluk hidup selalu berperan aktif bahkan mendominasi segala kegiatan yang terjadi di bumi dibanding dengan makhluk hidup yang lain. Ini dikarenakan manusia sebagai makhluk tuhan yang paling sempurna dianugrahi akal dan fikiran. Oleh sebab itu perananan sumber daya manusia secara perorangan maupun kelompok mempunyai peranan penting bagi perusahaan. Parlinda dan Wahyudin (2003) menyatakan bahwa sumber daya manusia yang dimiliki perusahaan menjadi penentu sukses atau tidaknya suatu perusahaan dalam mencapai tujuan. Meskipun dengan memiliki sarana dan prasarana yang baik tetapi tanpa dukungan sumber daya manusia yang handal, maka seluruh kegiatan perusahaan tidak akan terlaksana. Maka dari itu untuk menciptakan sumber daya yang unggul perusahaan perlu menghargai segala aspek yang ada didalam diri setiap karyawan. Menurut Lewa (2005:56), tujuan perusahaan diharapkan dapat tercapai melalui kinerja sumber daya manusia yang tinggi. Untuk mencapai tujuan tersebut perusahaan harus memperhatikan faktor - faktor yang dapat mempengaruhi kinerja karyawannya.

Untuk perusahaan jasa sekelas RSU Kertha Usada melakukan pemberdayaan karyawan ditengah pandemi COVID-19 dapat dijadikan upaya menciptakan suasana kerja yang kondusif bagi karyawan sehingga karyawan dapat melakukan pekerjaan secara maksimal. Hal ini 
dikarenakan di tengah pandemi tenaga kesehatan khususnya perawat dituntut untuk lebih cekatan dalam melaksanakan tugas dan kewajibannya. Munandar (2001) menyebutkan bahwa beban kerja adalah keadaan dimana pekerjaan harus diselesaikan dalam batas waktu tertentu.

Siagian (2002) menyatakan bahwa kompensasi,,budaya organisasi, kepemimpinan, dan lingkungan kerja menjadi faktor yang mempengaruhi kinerja karyawan. Dalam ruang lingkup perusahaan, selain melaksanakan tugas sesuai dengan jabatan, karyawan juga dituntut untuk melakukan adaptasi dengan lingkungan termasuk rekan kerja yang memiliki karakter berbeda beda. Menurut Nitisemito (1996:109), lingkungan kerja merupaka segala hal yang terdapat disekitar karyawan dan dapat mempengaruhi mereka dalam menjalankan tugas-tugas yang dibebankan. Sementara Saydam (2000:226) mendefinisikan keseluruhan sarana prasarana kerja yang ada disekitar karyawan sebagai lingkungan kerja yang dapat mempengaruhi pelaksanaan pekerjaan itu sendiri. Menciptakan lingkungan kerja yang kondusif dan aman mampu memacu semangat karyawan mengerjakan tugas secara produktif hal ini dapat dilakukan oleh pihak RSU Kertha Usada sebagai induk perusahaan. Terciptanya lingkungan kerja yang baik akan memberikan kepuasan tersendiri bagi karyawan dan mampu memberikan kesan baik sehingga karyawan akan lebih semangat dalam mengerjakan tugasnya dan upaya tersebut juga akan memberikan dampak baik pula terhadap citra perusahaan.

Ditengah pandemi COVID-19 lingkungan kerja RSU Kertha Usada menjadi kurang kondusif. Pasien yang dirawat dirumah sakit memiliki potensi menularkan virus Corona kepada para perawat, meskipun RSU Kertha Usada bukan rumah sakit rujukan COVID-19 di kabupaten Buleleng. Sebagai perusahaan RSU Kertha Usada dituntut lebih untuk memberikan keamanan kepada perawat dalam menjalankan tugasnya. Tenaga kesehatan berhak mendapat perlakuan yang sesuai dengan harkat dan martabat manusia, pelindungan atas keselamatan dan kesehatan kerja, moral, kesusilaan, serta nilai-nilai agama, hal ini dinyatakan dalam pasal 57 UU 36 Tahun 2014 pada poin keempat. Upaya melindungi serta menjaga keamanan dapat dilakukan dengan memberikan fasilitas yang sesuai untuk keamanan dan kenyamanan perawat, seperti memberikan APD untuk fasilitas penunjang kerja.

Indikator - indikator lain yang juga harus diperhatikan oleh perusahaan seperti memperhatikan hubungan antar rekan kerja serta hubungan antara atasan dengan bawahan. Hal ini dikarenakan lingkungan kerja memiliki pengaruh penting terhadap karyawan yang bekerja meskipun lingkungan kerja tidak melaksanakan proses produksi dalam perusahaan. Menurut Sedarmayanti (2009:35), hubungan sosial karyawan merupakan lingkungan non fisik. Sebenarnya dapat dipahami bahwa dinamika kelompok dapat berpengaruh terhadap hubungan sosial pekerja. Sengkey, dkk (2017) menyatakan secara parsial lingkungan kerja berpengaruh signifikan dan positif terhadap kinerja karyawan. Hasil penelitian serupa juga dilakukan oleh Pratama dan Wismarein (2018) yang menunjukkan bahwa secara parsial lingkungn kerja berpngaruh positif signiifikan terhadap kinerja karyawan.n

Pandemi COVID-19 yang semakin hari semakin parah mengharuskan perawat selalu menghadapi berbagai gelombang pasien yang mempunyai gejala atau positif COVID-19. Risiko yang dihadapi tentu sangat rentan tertular virus Corona ditengah kewajiban menangani para pasien. Stigma negatif terkait perawat yang beredar dimasyarakat membuat para perawat dikucilkan di lingkungan masyarakat, seperti kasus perawat RSUD Bung Karno Solo sebanyak tiga orang yang diusir dari kost karena dianggap berpotensi menularkan COVID-19 kepada masyarakat (Suarajawatengah.id). Melalui akun Instagram, Ikatan Dokter Indonesia (IDI) mencatat dokter yang meninggal karena terpapar Corona sebanyak 37 orang. Hingga Jumat,19 Juni 2020 (PPNI) Persatuan Perawatan Indonesia mendata terdapat 123 perawat yang dikatakan positif dan meninggal dunia 26 di antaranya dalam situs resminya. Sementara (dalam Tirto.id, 2020) Pusat Ikatan Bidan Indonesia menyatakan bahwa bidan yang positif COVID-19 per 9 Juni 2020 ada 218 dan di antaranya 48 orang berstatus (PDP) pasien dalam pengawasan.

Selain faktor lingkungan kerja masalah - masalah yang terjadi dimasa pandemi dapat menjadi pemicu timbulnya stres kerja yang sekaligus menjadi factor yang mempengaruhi kinerja perawat. Dalam penelitian Mariskha (2011) menyebutkan bahwa stres kerja 
mempengaruhi kinerja karyawan. Berbeda dengan penelitian Kuong dan Yen (2016) menyatakan bahwa kinerja karyawan dipengaruhi oleh stres kerja. Stres kerja merupakan proses berpikir, emosi,dan kondisi fisik seseorang yang diakibatkan oleh beban akibat bekerja, di mana beban tersebut berasal dari lingkungan pekerjaan tempat individu tersebut bekerja (Yoder dan Staudohar 1982: 308). Dari tingkatan penyebab variabel stres apabila tidak segera dilakukan langkah antisipasi terhadap penyebab terjadinya stres kerja akan dapat mempengaruhi karyawan dalam bekerja.

Stres dalam jangka pendek, jika tidak ditangani akan membuat karyawan merasa tertekan dan frustasi sehingga membuat kinerja karyawan menjadi tidak optimal. Untuk jangka panjang, karyawan yang tidak dapat menahan stres kerja mengakibatkan karyawan tersebut sering tidak masuk kerja. Karyawan bisa mengundurkan diri dari perusahaan ketika pada tahap yang semakin parah. Namun hal ini berbeda dengan penelitian Dewi, dkk (2014) yanggmenunjukkan bahwaastres kerja terhdap kinerja karywan secara parsial ada pengauh negatif dan signifikan. Sejalan dengan Wenur, dkk (2018), yang hasil penelitiannya menunjukkan bahwa tidak ada pengaruh yang signifikan stres kerja terhadap kinerja karyawan.

\section{Metode}

Penelitian kuantitatif merupakan metode pada penelitian ini dengan menggunakan desain penelitian kausal yang digunakan untuk mengetahui hubungan variabel terikat dengan variabel bebas. RSU Kertha Usada menjadi subjek penelitian. Sedangkan ingkungan kerja $\left(\mathrm{X}_{1}\right), 1$ strs kerja $\left(\mathrm{X}_{2}\right)$, dan kinerjaa(Y) merupakan objek penelitian.Populasi penelitian ini adalah perawat tetap yang masih aktif bekerja di RSU Kertha Usada yang berjumlah 147 perawat.

Purposive sampling yaitu teknik pengambilan sampel yang digunakan. Teknik mengambil berdasarkan atas adanya pertimbangan yang berfokus pada tujuan tertentu artinya sampel diambil dengan tidak berdasarkan random, daerah atau strata Arikunto (2005). Jumlah minimal sampel ditentukan berdasarkan rumus Slovin (Sugiyono, 2011:37). Berdasarkan hasil perhitungan diperoleh sampel sejumlah 107 responden. Teknik pengumpulan data responden menggunakan metode kuisioner. Kuesioner tertutup adalah kuesioner yang digunakan dalam penelitian ini. Memberi beberapa pernyataan tertulis kepada responden untuk di jawab merupakan teknik pengumpulan data yang dilakukan.

Selanjutnya data kuisioner diuji menggunakan pengujian validitas instrumen dan pengujian reablilitas. Untuk mengukur sejauh mana instrumen dapat digunakan diuji dengan uji validitas digunakan, sedangkan sejauh mana instrumen pengukur dapat dipercaya atau diandalkan uji dengan uji reliabilitas. Dalam penelitian ini peneliti menggunakan (Path Analysis) analisis jalur sebagai alat analisis data. Analisis jalur dignakan untuk menganaisis pola hubungan tidak langsung. Irianto (2012: 283) menyatakan bahwa analisis jalur merupakan pengembaangan analisis regresi berganda yang menguraiikan besaran pengaruh dari variabel bebas terhadap variabel terikat secara tidak langsung. Analisis ini digunakan untuk mengetahui besarnya pengaruh langsung, tidak langsung serta pengaruh total variabel lingkungan kerja, stres kerja, dan kinerja perawat di RSU Kertha Usada ditengah pandemi COVID-19.

\section{Hasil dan Pembahasann}

Berdasarkan perhitungan uji statistik Pathh Analysiss dengann menggunakan bantun program (SPSS) Statistical Package for Social Science 23.0 for windows. Maka untuk perhitungan pengaruh variabel lingkungan kerja, stres kerja terhadap kinerja perawat pada RSU Kertha Usada ditengah pandemi COVID-19 diperoleh hasil yang digambarkan sebagai berikut. 


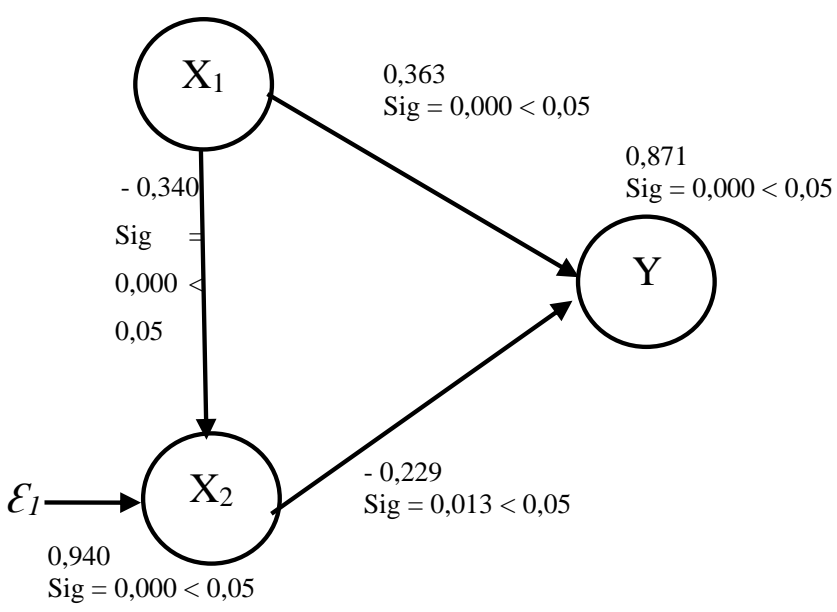

Dari gambar diatas, pada uji hipotesi pengaruh lingkungan kerja dan stress kerja terhdap kinerja memperoleh nilai Sig 0,000 $<0,05$. Hasil tersebut berarti hipotesis menolak Ho, sehingga dapat diputuskan bahwa ;ingkungan kerja dan stres kerja berpengaruh terhadap kinerja.a

Selanjutnya pada uji pengaruh lingkungan kerja terhadap kinerja memperoleh nilai Sig sebesar $0,000<0,05$. Hal ini berarti bahwa hipotesis menolak Ho, sehingga dapat dikatakan bahwa lingkungan kerja berpengaruh terhadap kinerja.

Berikutnya pada uji pengaruhhstres kerja terhadap kinerja memperoleh nilai Sig 0,013 < 0,05.Nilai tersebut menunjukan bahwa stres kerja berpengaruh terhadap kinerja karena hipotesis menolak Ho.

Pada uji hipotesis pengaruh lingkungannkerjaaterhadap stres kerjaamemperoleh hasil Sig $0,000<0,05$. Hasil tersebut berarti ada pengaruh lingkungan kerja terhadap kinerja karena hipotesis menolak Ho.

Tabel 1. Sumbangan Pengaruh Variabel Lingkungan Kerja $\left(X_{1}\right)$ dan Stres Kerja $\left(X_{2}\right)$ terhadap Kinerja Perawat (Y) Pada RSU Kertha Usada ditengah Pandemi COVID-19.

\begin{tabular}{lcc}
\hline Keterangan & $\begin{array}{c}\text { Besar } \\
\text { Sumbangan }\end{array}$ & $\begin{array}{c}\text { Persentase } \\
(\%)\end{array}$ \\
\hline Besar pengaruh langsung $X_{1}$ terhadappY & 0,363 & $36,3 \%$ \\
Besar pengaruh tidak langsungg $X_{11}$ terhadappY melalui $X_{2}$ & 0,077 & $7,7 \%$ \\
Besar pengaruh langsung $X_{1}$ terhadap $X_{2}$ & 0,340 & $34 \%$ \\
Besar pengaruh total $X_{1}$ terhadap $Y 1$ melalui $X_{2}$ & 0,440 & $44 \%$ \\
Besar pengaruh langsung $X_{2}$ terhadap $Y 2$ & 0,229 & $22,9 \%$ \\
Besar pengaruh total $X_{1}$ dan $X_{2}$ terhadap $Y$ & 0,241 & $24,1 \%$ \\
Besarrpengaruh lain $X_{1}$ dan $X_{2}$ terhadap $Y$ & 0,759 & $75,9 \%$ \\
\hline
\end{tabular}

Berdasarkan tabel diatas maka dapat dilihat bahwa lingkungan kerja secara positiff berpengaruh terhadap kinerja perawat RSU Kertha Usada. Temuan ini sejalan dengan pendapat Terry (2006:23) yang menyebutkan bahwa hal-hal yang mampu mempengaruhi baik secara tidak langsung ataupun langsung terhdap kinerja karyawan maupun organisasi dalam suatu perusahaan adalah lingkungan kerja. Sedangkan Khoriyah (2009) berpendapat bahwa hal penting dalam pencapaian kinerja karyawan terdapat pada lingkungan kerja yang dimiliki. Temuan diperkuat dengan hasil penelitian Sari,dkk (2017) yang menyatakan bahwa lingkungan kerja berpengaruh positif terhadap kinerja.

Jika dilihat dari karakteristik responden jumlah persentase perawat perempuan lebih mendominasi dibandingkan laki - lakiidengan rata - rata usia 21 tahunnsampai 31 tahun. Maka dari itu hal-hal yang harus dilakukan oleh pihak RSU Kertha Usada dalam meningkatkan 
lingkungan kerja dengan memperhatikan indikator - indikator yang mempengaruhi lingkungan kerja itu sendiri. Seperti menciptakan suasana kerja yang tenang dan kondusif akan membuat perawat merasa aman ketika berada di lingkungan RSU Kertha Usada. Memberikan fasilitas yang memadai dan sesuai dengan kebutuhan perawat dapat upaya untuk memenuhi fasilitas kerja perawat. Karena mayoritas perawat di RSU Kertha Usada perempuan, penting bagi pihak RSU Kertha Usada lebih memperhatikan hubungan kerja antar perawat. Karena pada umumnya perempuan cenderung lebih sensitif dan mudah tersinggung, maka perusahaan dapat menumbuhkan sikap saling menghormati dan menghargai antar perawat, melakukan komunikasi atau interaksi dalam setiap kesempatan, serta selalu bersikap adil terhadap tiap perawat.

Hasil penelitian mengenai pengaruhhstres kerja terhadap kinerja perawat menunjukkan bahwa secara negatif stres kerja berpengaruh terhadap kinerja perawat RSU Kertha Usada. Sesuai dengan hasil penelitian Difayoga,dkk (2015) yang menyebutkan bahwa stres kerja memilikii pengaruhhnegatif signifikan terhadap kinerja.aMenurut Tuten dan Neidermeyer (2004) stres pada karyawan harus dihindari untuk mempertahankan serta meningkatkan kinerja karyawan, dikarenakan stres kerja dapat berimplikasi pada penurunan kinerja. Tingkat stres yang berlebihan mampu menurunkan kinerja karyawan (Warraich et al. 2014). Sebagai pihak perusahaan upaya yang dapat dilakukan RSU Kertha Usada dalam menurunkan stres kerja perawat dengan memberikan dukungan dan dorongan dalam bentuk motivasi kepada perawat. Hasil penelitian Irkhami (2015) menyatakan bahwa pekerja dengan usia 21 tahun sampai 40 tahun lebih banyak mengalami tingkat stres kerja tinggi. Kemudian Menurut Deekshitulu (2012) menyebutkan bahwa pada saat perempuan mendapat tekanan, pada umumnya akan lebih mudah mengalami stres. Sehingga motivasi sangat penting diberikan oleh RSU Kertha Usada kepada perawat. Pemberian motivasi dapat dilakukan dengan cara menghargai aspirasi perawat, memberikan apresiasi atas kinerja perawat, serta menciptakan lingkungan kerja yang menyenangkan bagi perawat. Pemberian motivasi pada umumnya wajib dilakukan oleh pihak perusahaan karena akan memberikan dampak baik bagi perusahaan.

Hasil penelitian menjelaskan ada pengaruh secara negative dan signifikan antara lingkungn kerja terhadap stress kerja perawat RSU Kertha Usada. Penelitian ini sejalan dengan penelitian Lahat (2018) yang menyebutkan lingkungan kerja berpengaruh negatif signifikan terhadap stres kerja. Robbinsn(2008:370) menytakan bahwa faktor lingkunganikerja, faktor perushaan, dan faktor pribadi sebagai tiga kategori pemicu stres kerja. Pengaruh negatif dalam artian meningkatnya kualitas lingkungan kerja mampu menurunkan stress kerja yang dihadapi perawat. Maka dari itu lingkungan kerja baik sangat berpengaruh terhadap karyawan dalam mengerjakan kewajibannya dan secara bersamaan membantu menurunkan tingkattstres para karyawan, begitu juga sebaliknya.

Pada hasil penelitian menyatakan bahwa ada tambahan pengaruh tidak langsung lingkungan kerja terhadap kinerja melalui stres kerja. Penelitian ini dapat menjadi perhatian bagi pihak RSU Kertha Usada untuk mengelola stress kerja terdahulu disertai dengan perbaikan lingkungan kerja guna meningkatkan kinerja dibandingkan dengan fokus pada salah satu variabel saja.

\section{Simpulan dan Saran}

Berdasarkan analisis data serta pembahasan hasil penelitian dapat disimpulkan bahwaalingkungan kerjaadan stress kerja secara signifikan berpengaruh tehadap kinerja perawat RSU Kertha Usada. Selain ituulingkungan kerjaajuga memiliiki pengaruh positiffdan signifikan terhadap kinerja perawat RSU Kertha Usada. Selanjutnya secara negatif dan signifikan stres kerja mempengaruhi kinerja perawat RSU Kertha Usada. Selain itu lingkungan kerja secara negatif dan signifikan mempengaruhi stres kerja perawat RSU Kertha Usada.

Dari kesimpulan dan implikasi hasil penelitian, ada beberapa saran yang peneliti ingin ajukan sebagai berikutt: (1) Kepada pihak RSU Kertha Usada, diharapkan untuk selalu memperhatikan lingkungannkerja dan stresskerja yang dialami oleh perawat. Sebagaimana hasil penelitian diatas yang menunjukkan bahwa lingkungan kerja dan stes kerja memilliki 
pengaruh signfikan terhadap kinerja perawat. Sehingga hal ini dapat dianggap penting guna terus meningkatan kinerja perawat. Peningkatan kinerja perawat tentunya akan berdampak baik terhadap citra perusahaan. Hal-hal dapat dilakukan untuk meningkatkan kinerja perawat adalah menyediakan fasilitas yang sesuai dengan kebutuhan karyawan. Karena fasilitas yang baik akan mempermudah karyawan dalam melakukan pekerjaan. Serta selalu memperhatikan hubungan antar karyawan baik melalui komunikasi atau interaksi lainnya. (2). Kepada pihak peneliti nantinya yang memiliki ketertarikan mengkaji aspek yang sama diharapkan untuk dapat melakukan pengembangan terhadap penelitian dengan subjek penelitian yang lebih luas. Selain itu diharapkan juga untuk meneliti variabel lain yang mempengaruhi kinerja karyawan.

\section{Daftar Pustaka}

Deekshitulu B. 2012. Stres dan Yoga. Journal of Yoga \& Physical Therapy.

Dewi, Utari dkk. 2014. Manajemen Keuangan: Kajian Praktik dan Teori dalam Mengelola Keuangan Organisasi Perusahaan. Jakarta: Mitra Wacana Media.

Difayoga, Rama dan Ahyar Yuniawan. (2015). Pengaruh Stres Kerja, Kepuasan Kerja, dan Lingkungan Kerja Terhadap Kinerja Perawat (Studi Pada RS Panti Wilasa Citarum Semarang. Diponegoro Journal Of Management, Volume 4, Nomor 1, Tahun 2015.

Gabreila,Wenur, Jantje, Lucky. (2018). Pengaruh Stres Kerja dan Konflik Kerja Terhadap Kinerja Karyawan Pada PT. Bank Negara Indonesia (PERSERO) tbk Cabang Manado.

Gibson, J. L. Dkk. (1997). Organisasi dan Manajemen. Jakarta; Penerbit Erlangga

Hasibuan, Malayu S.P, 2006, Manajemen Dasar, Pengertian, dan Masalah, Edisi Revisi, Bumi Aksara:Jakarta.

Irianto, Agus. 2012. Statistika Konsep Dasar, $\quad$ Aplikasi dan Pengembangannya. Jakarta: Kencana Prenada Media Group.

Irkhami, Faris Lazwar. 2015. "Faktor yang berhubungan dengan Stres Kerja pada Penyelam di Pt.X". Health Safety Evironmental (KSE) Pertamina Gresik. The Indonesian Journal of Occupational Safety and Health Vo.4 No.1

Khoiriyah, Lilik. 2009. Pengaruh Upah dan Lingkungan Kerja Terhadap Kinerja Karyawan Pada CV. AJI BALI JAYA WIJAYA SURAKARTA. Skripsi, S1,UMS, Dipublikasikan.

Khuong, Mai Ngoc dan Vu Hai Yen. (2016). Investigate the Effects of Job Stress on Employee Job Performance A - Case Study at Dong Xuyen Industrial Zone, Vietnam.

Lahat, Amas Mohammad (2018). Pengaruh Lingkungan Kerja Terhadap Stres KerjaKaryawan Pada PT. Pandu Siwi Sentosa Jakarta. Jurnal Penelitian Ekonomi dan Bisnis. Vol 2. No.2. Desember 2018

Lewa, Eka Idham lip K dan Subowo. 2005. Pengaruh Kepemimpinan, Lingkungan Kerja Fisik dan Kompensasi Terhadap Kinerja Karyawan DiPT. Pertamina (Persero Daerah Operasi Hulu Jawa Bagian Barat, Cirebon. Jurnal Sinergi Edisi Khusus on Human Resources:129-140

Mangkunegara, A. Anwar Prabu (2016). Manajemen Sumber Daya Manusia Bandung: PT.Remaja Rosdakarya, Bandung.

Mariskha Z. (2011). Pengaruh Stres Kerja dan Kepuasan Kerja Terhadap Kinerja Karyawan Surat Kabar Harian Lokal di Kota Palembang. Jurnal Ilmiah Orasi Bisnis: tidak diterbitkan.

Munandar, S (2001). Psikologi Industri dan Organisasi. Jakarta : UI. 
Pratama, Yosef Ferry dan Dian Wismar'ein, Pengaruh Pelatihan dan Lingkungan Kerja Terhadap Kinerja Karyawan, Universitas Muria Kudus, Business Manajement Analysis Journal (BMAJ) Vol. 1 No. 1 Oktober 2018 dalam https://jurnal.umk.ac.id/index.php/bmaj/ article/download/2686/1467 diakses pada tanggal 28 September 2018.

Sari, Indah Liana, Victor P. K. Lengkong dan Jntje L. Sepang.(2017). Pengaruh

Stres Kerja dan Lingkungan Kerja terhadap Kinerja Karyawan: Studi Kasus PT. Wenangcemerlang Press. urnal EMBA, Vol. 5, No. 3,September:4445-4454

Sedarmayanti, 2015, Manajemen Sumber Daya Manusia, Reformasi Birokrasi dan.Manajemen karyawan Negeri Sipil, Cetakan kelima. Refika. Aditama, Bandung.

Sengkey Windri S. Dkk. 2017. Pengaruh Lingkungan Kerja dan Stres Kerja Terhadap Kinerja Karyawan PT. PLN (Persero) Wilayah Suluttenggo Area Manado.

Sugiyono. 2013. Metode Penelitian Pendidikan Pendekatan Kuantitatif, Kualitatif, dan $\quad R \& D$. Bandung: Alfabeta.

Suprihanto John, dkk., 2003. Perilaku Organisasional. Yogyakarta: Sekolah Tinggi IImu Ekonomi YKPN.

Terry, George R. (2016). Manajemen Sumber Daya Manusia, Jakarta : CV Haji Masagung

Tuten, T. L.\& Neidermeyer, P. E. 2004., "Performance, Satisfaction, and Turnover in Call Centers, The Effect of Stress and Optimism". Journal of Business Research.

Wahyudi, A. dan J. Suryono. 2006. Analisis Pengaruh Gaya Kepemimpinan, Motivasi, dan Lingkungan Kerja Terhadap Kinerja Karyawan .Jurnal Manajemen Sumber Daya Manusia, Vol. 1 No. 1.Desember $2006:$ 1-14.

Warraich, Usman Ali et al. 2014. Customer Retention in Fast Food Industry. IJMS. Vol.1 No. 1. 